Aaronson, S. (1955). J. gen. Microbiol. 12, 147-155.

\title{
The Purine Requirement of Staphylococcus flavocyaneus
}

\author{
By S. AARONSON \\ Haskins Laboratories and the Biology Department, Queens College, \\ New York, N.Y., U.S.A.
}

\begin{abstract}
SUMMARY: Staphylococcus flavocyaneus, grown in chemically defined media, requires a purine; adenine, hypoxanthine, their respective ribosides and ribotides, 4-amino-5-imidazolecarboxamide or 4-amino-5-imidazolecarboxamidine were effective. Per mole, the ribotides $\left(2^{\prime}, 3^{\prime}\right.$ or $\left.5^{\prime}\right)$ were most efficient. Growth with effective purines is inhibited by guanine and certain unnatural purines. Inhibition of growth by purines may involve two mechanisms: one concerned with the synthesis of unnatural nucleic acid; the other with a crippling of ribose metabolism.
\end{abstract}

Guanine inhibits the growth of several purine-requiring organisms (Pennington, 1942; Fairley \& Loring, 1949; Pontecorvo, 1950; Northam \& Norris, 1951; Pomper, 1952). Staphylococcus flavocyaneus (Knaysi, 1942) was also inhibited (S. H. Hutner, unpublished observation); this inhibition has now been studied as an approach to the investigation of purine metabolism.

\section{METHODS}

The culture methods and measurements of growth responses used for Staphylococcus flavocyaneus (NCTC 7011) were similar to those used by Baker, Sobotka \& Hutner (1953) for bacilli. Cultures were incubated at $37^{\circ}$. Although 3-4 days usually sufficed for growth with some compounds, cultures were allowed to grow for 10-14 days to allow the more slowly utilized but more active ribotides to be maximally used.

Stock cultures were grown on: $\mathrm{K}_{2} \mathrm{HPO}_{4}, 0.02 \mathrm{~g}$.; $\mathrm{Na}_{3}$ citrate. $2 \mathrm{H}_{2} \mathrm{O}, 0.05 \mathrm{~g}$.; $\mathrm{Na}$ acetate $.3 \mathrm{H}_{2} \mathrm{O}, 0.03 \mathrm{~g}$.; $\mathrm{Na}_{2}$ succinate. $6 \mathrm{H}_{2} \mathrm{O}, 0.02 \mathrm{~g}$.; Trypticase (Baltimore Biological Laboratory), 0.05 g.; yeast autolysate (Albimi Laboratories, Brooklyn, N.Y.), $0 \cdot 1$ g.; corn starch, $0 \cdot 2$ g.; agar, 1.6 g.; distilled water to $100 \mathrm{ml}$; pH 7.0.

Purines and nucleic acid derivatives were obtained from commercial sources. The imidazoles and 2:6-diaminopurine were obtained through the generosity of Dr M. E. Balis of the Sloan-Kettering Institute for Cancer Research and the 8-azaguanine through the generosity of Dr G. H. Hitchings of the Wellcome Research Laboratories (Tuckahoe, New York, U.S.A.). The nucleic acid derivatives and analogues were tested for homogeneity with single-dimension ascending paper chromatography using the following solvent systems: $\mathrm{Na}_{2} \mathrm{HPO}_{4} \cdot 12 \mathrm{H}_{2} \mathrm{O}, 5 \%$ (w/v) saturated with isoamyl alcohol (Carter, 1950), or butanol: glacial acetic acid: $\mathrm{H}_{2} \mathrm{O}(4: 1: 5, \mathrm{v} / \mathrm{v}$, Buchanan, Dekker \& Long, 1950). 


\section{RESULTS}

\section{Nutrition}

The basal medium (Table 1) was adequate for the growth and multiplication of Staphylococcus flavocyaneus upon addition of a purine. The main carbon and energy source was glucose, sucrose, or acetate; the combination of acetate + sucrose was optimal. Nitrogen could be supplied by $\mathrm{NH}_{4} \mathrm{Cl}$ or L-glutamic acid (which also served as a supplementary carbon source); sulphur was provided by either $\mathrm{MgSO}_{4} .7 \mathrm{H}_{2} \mathrm{O}$, DL-methionine, or L-cystine. The optimal $\mathrm{pH}$ range was $7 \cdot 5-8 \cdot 0$.

Table 1. Basal medium for Staphylococcus flavocyaneus

\begin{tabular}{|c|c|c|c|}
\hline \multicolumn{4}{|c|}{$\mathrm{MgSO}_{4} .7 \mathrm{H}_{2} \mathrm{O} \quad 0.05 \mathrm{~g} . \quad \mathrm{Mo}\left(\right.$ as $\left.\mathrm{Na}_{2} \mathrm{MoO}_{4} .2 \mathrm{H}_{2} \mathrm{O}\right)$} \\
\hline \multicolumn{4}{|c|}{$\mathrm{KH}_{2} \mathrm{PO}_{4} \quad 0.01 \mathrm{~g}$. Ca (as chloride) } \\
\hline $\mathrm{NH}_{4} \mathrm{Cl}$ & $0.05 \mathrm{~g}$. & \multirow{2}{*}{\multicolumn{2}{|c|}{$\begin{array}{l}\text { Trace metals solution* } \\
\text { Distilled water to } 100 \mathrm{ml} \text {. }\end{array}$}} \\
\hline $\mathrm{Na}$ acetate $.3 \mathrm{H}_{2} \mathrm{O}$ & $0 \cdot 4 \mathrm{~g}$ & & \\
\hline Sucrose & $1.0 \mathrm{~g}$. & \multicolumn{2}{|l|}{$\mathrm{pH} \mathrm{7 \cdot 6-8 \cdot 0}$} \\
\hline -Glutamic acid & $0.5 \mathrm{~g}$. & & \\
\hline \multicolumn{4}{|c|}{ * Trace metals solution $1.0 \mathrm{ml}$. contains the following: } \\
\hline \multirow{4}{*}{$\begin{array}{l}\mathrm{Zn}\left(\text { as } \mathrm{ZnSO}_{4} \cdot 7 \mathrm{H}_{2} \mathrm{O}\right) \\
\mathrm{Mn}\left(\text { as } \mathrm{MnSO}_{4} \cdot \mathrm{H}_{2} \mathrm{O}\right) \\
\mathrm{Fe}\left(\text { as } \mathrm{FeSO}_{4} \cdot 7 \mathrm{H}_{2} \mathrm{O}\right) \\
\mathrm{B}\left(\text { as } \mathrm{H}_{3} \mathrm{BO}_{3}\right)\end{array}$} & $1.0 \mathrm{mg}$. & \multirow{4}{*}{$\begin{array}{l}\mathrm{Cu}\left(\text { as } \mathrm{CuSO}_{4} \cdot 5 \mathrm{H}_{2} \mathrm{O}\right) \\
\mathrm{Co}\left(\text { as } \mathrm{CoSO}_{4} \cdot 7 \mathrm{H}_{2} \mathrm{O}\right) \\
\text { Ethylenediamine tetra-acetic } \\
\text { acid }\end{array}$} & 0.2 \\
\hline & $1.6 \mathrm{mg}$. & & \\
\hline & $0 \cdot 8 \mathrm{mg}$. & & \\
\hline & $0.4 \mathrm{~m}$ & & $0 \cdot 0$ \\
\hline
\end{tabular}

Table 2. Compounds which satisfy the purine requirement of

Staphylococcus flavocyaneus, and some which do not

\begin{tabular}{|c|c|c|c|}
\hline \multicolumn{2}{|l|}{ Utilized } & \multicolumn{2}{|l|}{ Not utilized } \\
\hline & $\begin{array}{l}\text { Conc. range } \\
\text { tested } \\
\text { (mg./100 ml.) }\end{array}$ & & $\begin{array}{c}\text { Conc. range } \\
\text { tested } \\
\text { (mg. } / 100 \mathrm{ml} .)\end{array}$ \\
\hline Adenine* & $0 \cdot 01-100$ & Cytosine & 2 \\
\hline Hypoxanthine* & $0 \cdot 01-100$ & Barbituric acid & 2 \\
\hline Adenosine* & $0.01-100$ & Orotic acid & 2 \\
\hline Inosine* & $0 \cdot 01-30$ & 5-Aminouracil & 2 \\
\hline Adenosine-2'-phosphate* & $0 \cdot 01-100$ & Thymine & $1-50$ \\
\hline Adenosine-3'-phosphate* & $0 \cdot 01-100$ & Uracil & $\mathbf{1 - 5 0}$ \\
\hline Adenosine-5'-phosphate & $0 \cdot 01-100$ & Guanine & $0.01-5$ \\
\hline Inosine-5'-phosphate & $0 \cdot 01-100$ & 8-Azaguanine & $0.01-50$ \\
\hline Adenosine triphosphate & $0 \cdot 1-25$ & 2:6-Diaminopurine. $\mathrm{HCl}$ & $0.01-50$ \\
\hline 4-Amino-5-imidazole- & & Uric acid & $1-50$ \\
\hline carboxamide & $0 \cdot 01-84$ & Allantoin & $1-50$ \\
\hline 4-Amino-5-imidazole- & & Caffeine & $\mathbf{1}-50$ \\
\hline carboxamidine & $0 \cdot 01-100$ & Theophylline & $\mathbf{1}-50$ \\
\hline Stimulatory (in the presen & e of the above*) & Theobromine & $1-50$ \\
\hline Xanthine & $0 \cdot 01-3$ & L-Histidine & $1-50$ \\
\hline & & 4:5-Dicarboxyimidazole & $2-20$ \\
\hline
\end{tabular}

\section{Purine utilization}

Adenine, hypoxanthine, their corresponding ribosides and ribotides, 4-amino-5-imidazolecarboxamidine ('amidine'), or 4-amino-5-imidazolecarboxamide ('carboxamide') satisfied the purine requirement (Table 2). The imidazoles correspond in configuration to adenine and hypoxanthine respectively (Fig. 1). 
Utilization of purines and their derivatives was compared on a molar basis (Fig. 2). Growth appeared sooner with hypoxanthine, adenosine or inosine and lagged with adenine, the ribotides, amidine and carboxamide. Hypoxanthine, adenosine, and inosine satisfied the purine requirement at lower concentrations than did adenine or the ribotides (Fig. 2). At a concentration c. $1 \mu$ mole $/ 5 \mathrm{ml}$. adenine, hypoxanthine, or their respective ribosides fully satisfied the purine requirement. The ribotides (adenosine-2'-phosphate,<smiles>Nc1ncnc2[nH]cnc12</smiles>

Adenine<smiles>Oc1ncnc2[nH]nnc12</smiles>

Hypoxanthine<smiles></smiles>

4-Amino-5-imidazolecarboxamidine ('amidine')<smiles></smiles>

4-Amino-5-imidazolecarboxamide ('carboxamide')

Fig. 1. Structures of adenine, hypoxanthine and the imidazoles used.

adenosine-3'-phosphate, adenosine- 5 ' -phosphate, or inosine- $5^{\prime}$-phosphate) allowed either no growth or poor growth at low concentrations; at higher concentrations ( $>1 \mu \mathrm{mole} / 5 \mathrm{ml}$.) these ribotides supplied the needed purine moiety better than did their respective ribosides or free bases. The latter inhibited at $c .50 \mu \mathrm{mole} / 5 \mathrm{ml}$.

The response to 4-amino-5-imidazolecarboxamidine (Fig. 2) is characterized by a sharp peak; the abrupt drop in growth probably indicates toxicity. The response to 4-amino-5-imidazolecarboxamide was similar. The amidine allowed almost twice as much growth as the carboxamide at equal molarities, and also supported greater growth at the lower concentrations.

\section{Inhibition of purine utilization}

All the compounds which satisfied the purine requirement were inhibited by guanine and its analogues; inhibition curves for some of the compounds are shown in Fig. 3.

Hypoxanthine was chosen as the reference purine because low concentrations permitted good growth. Inhibition of hypoxanthine by guanine, guanosine and guanylic acid was in proportion to their guanine content. Growth was most diminished with ratios of guanine to hypoxanthine of $c .5$.

Several purine analogues interfered with the utilization of hypoxanthine (Table 3) and also with adenine, adenosine, and adenylic acid (Table 4); the 
guanine configuration seems essential for inhibition, for only compounds which contained guanine or had an amino group on carbons 2 or 6 were inhibitory. Guanine completely inhibited adenine utilization at the concentrations used in Fig. 3.

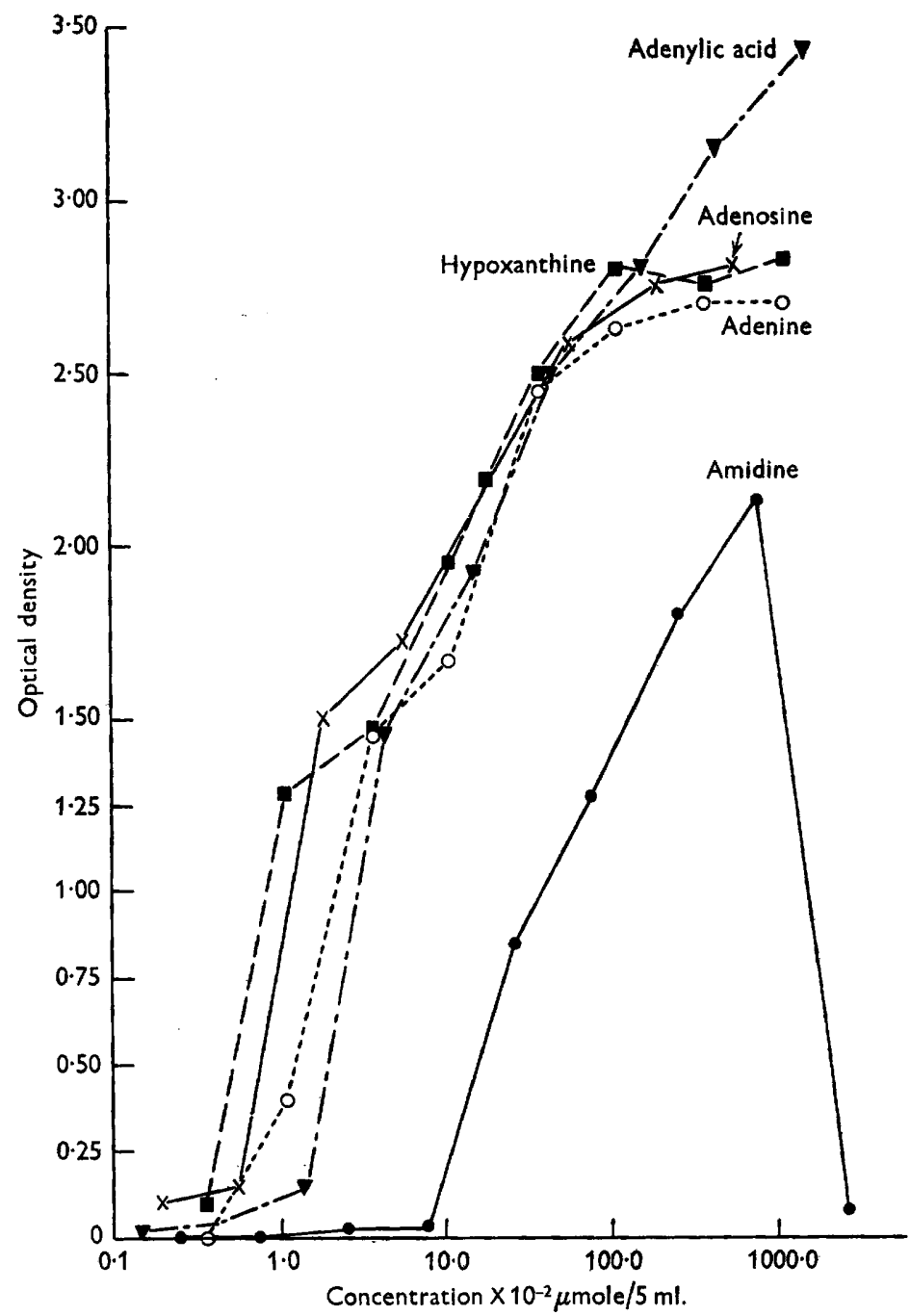

Fig. 2. Effect of purines and their derivatives on the growth of Staphylococcus flavocyaneus.

In this coccus the inhibition of growth by guanine and its riboside and ribotide is more effective than is inhibition by such purine analogues as 2:6-diaminopurine, 8-azaguanine, and isoguanine (Tables 3 and 4). The inhibition induced by these analogues (8-azaguanine was not tested) and guanine is partly or completely annulled by adenosine and adenylic acid (Table 4 and Fig. 3). 
Attempts to overcome the guanine inhibition with known compounds other than nucleic acid derivatives were unsuccessful. The ineffective compounds included (alone or in various mixtures): $p$-aminobenzoic acid, folic acid, folinic

Table 3. Inhibition of hypoxanthine utilization by purines, pyrimidines and their derivatives*

Conc. of hypoxanthine (mg./100 ml.

\begin{tabular}{l}
\multicolumn{1}{c}{ Compound } \\
Guanine \\
Guanosine \\
Guanylic acid \\
8-Azaguanine \\
2:6-Diaminopurine \\
Isoguanine \\
Uric acid \\
Thymine \\
Uracil \\
Caffeine \\
Theobromine \\
Theophylline
\end{tabular}

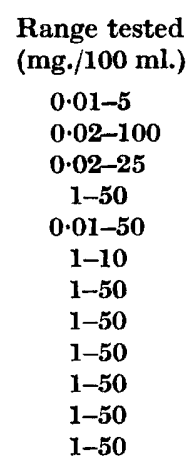

\begin{tabular}{|c|c|c|c|c|}
\hline \multicolumn{5}{|c|}{ Degree of inhibition } \\
\hline $\mathrm{Ct}$ & C & C & C & $\mathbf{P}$ \\
\hline- & C & C & $\mathbf{C}$ & - \\
\hline - & $\mathbf{C}$ & C & $\mathbf{P}$ & $\mathbf{P}$ \\
\hline C & $\ldots$ & $\mathbf{C}$ & $\mathbf{P}$ & $\mathbf{O}$ \\
\hline- & $\mathbf{P}$ & $\mathbf{P}$ & $\mathbf{O}$ & $\mathbf{O}$ \\
\hline - & $\mathbf{P}$ & - & $\mathbf{P}$ & $\mathbf{O}$ \\
\hline - & $\mathbf{0}$ & $\mathbf{O}$ & $\mathbf{O}$ & $\mathbf{0}$ \\
\hline- & - & $\mathrm{O}$ & $\mathbf{O}$ & $\mathbf{O}$ \\
\hline - & - & $\mathbf{O}$ & O & $\mathbf{O}$ \\
\hline- & $\ldots$ & $\mathbf{O}$ & $\mathbf{O}$ & $\mathbf{O}$ \\
\hline - & - & $\mathbf{O}$ & $\mathbf{O}$ & $\mathbf{O}$ \\
\hline - & - & $\mathrm{O}$ & $\mathbf{O}$ & $\mathbf{O}$ \\
\hline
\end{tabular}

* The results are a composite of many experiments.

$+\mathbf{C}=$ complete inhibition of growth within range; $\mathbf{P}=$ partial inhibition of growth (less than one-half of control); $\mathrm{O}=$ no inhibition of growth; $-=$ not tested.

Table 4. Comparison of various inhibitors on effect of several compounds utilized by Staphylococcus flavocyaneus

\begin{tabular}{|c|c|c|c|c|c|}
\hline \multirow{2}{*}{ Inhibitor } & \multirow{2}{*}{$\begin{array}{c}\text { Concentration } \\
\text { range } \\
\left(\times 10^{-2} \mu \mathrm{mole} / 5 \mathrm{ml}\right)\end{array}$} & \multicolumn{4}{|c|}{ 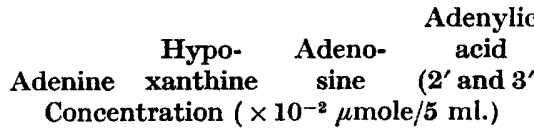 } \\
\hline & & \multicolumn{4}{|c|}{ Degree of inhibition } \\
\hline Guanine & $0 \cdot 33-99$ & $\mathrm{C}+$ & C & $\mathbf{P}$ & C \\
\hline Guanosine & $0 \cdot 33-99$ & C & $\mathbf{C}$ & $\mathrm{C}$ & $\mathbf{C}$ \\
\hline Guanylic acid & $0 \cdot 33-97$ & C & C & $\mathbf{C}$ & $\mathbf{C}$ \\
\hline Isoguanine & $0 \cdot 33-99$ & $\mathbf{P}$ & $\mathbf{P}$ & $\mathbf{0}$ & $\mathbf{O}$ \\
\hline 2:6-Diaminopurine. $\mathrm{HCl}$ & $0 \cdot 33-99$ & $\mathbf{P}$ & $\mathbf{P}$ ? & $\mathbf{0}$ & $\mathbf{0}$ \\
\hline Uric acid & $0 \cdot 37-112$ & $\mathbf{O}$ & 0 & $\mathbf{0}$ & $\mathbf{O}$ \\
\hline Xanthine & $0.33-99$ & $\mathbf{S}$ & $\mathbf{S}$ & $\mathbf{S}$ & $\mathbf{S}$ \\
\hline
\end{tabular}

* This concentration gives about one-third maximum growth.

$+\mathbf{C}=$ complete inhibition within range; $\mathbf{P}=$ partial inhibition; $\mathbf{P}$ ? = very slight inhibition; $\mathrm{O}=$ no inhibition; $\mathrm{S}=$ growth stimulation.

acid, the other $\mathbf{B}$ vitamins, and the common amino acids. Tests with complex materials such as beef extract, a tryptic digest of casein, and yeast autolysate indicated that only the beef extract had an activity possibly greater than that accounted for by its purine content (determined with a Beckman DU spectrophotometer). 


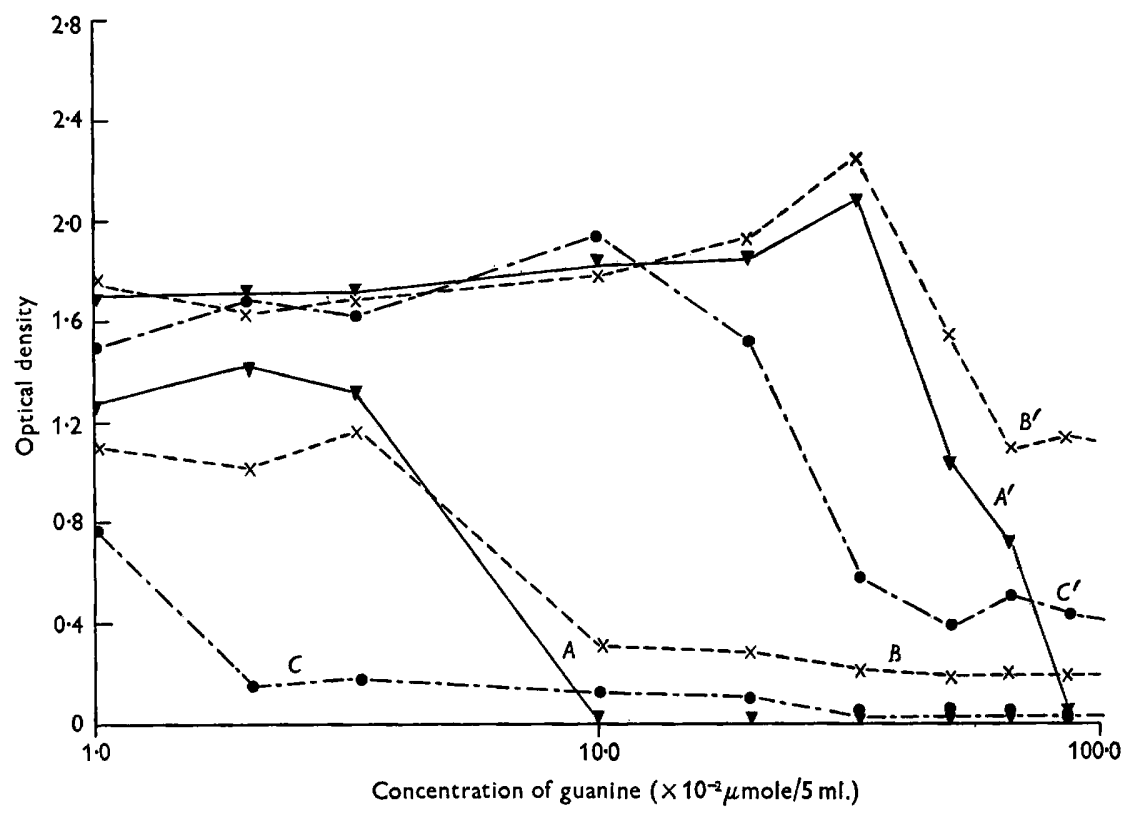

Fig. 3. Fffect of several purines and their derivatives on the inhibition by guanine. (Adenine was ineffective at these concentrations.) Key: - - , hypoxanthine, curve $A, 1.9 \times 10^{-2}$ $\mu$ mole $/ 5 \mathrm{ml}$; curve $A^{\prime}, 19 \times 10^{-2} \mu$ mole $/ 5 \mathrm{ml}$. - - - , adenosine, curve $B, 1.9 \times 10^{-2}$ $\mu$ mole $/ 5 \mathrm{ml}$.; curve $B^{\prime}, 19 \times 10^{-2} \mu \mathrm{mole} / 5 \mathrm{ml}$. _- - $-\ldots$, adenylic acid $\left(2^{\prime}\right.$ and $\left.3^{\prime}\right)$, curve $C, 1.8 \times 10^{-2} \mu \mathrm{mole} / 5 \mathrm{ml}$; curve $C^{\prime} 18 \times 10^{-2} \mu \mathrm{mole} / 5 \mathrm{ml}$.

\section{DISCUSSION}

Utilization of purines and their derivatives. McNutt (1952) discussed the vagaries of the utilization of free purine bases, ribosides, and ribotides by micro-organisms. The pattern of purine utilization by Staphylococcus flavocyaneus has precedents. At present there seems to be no general hypothesis for the differential utilization of the purine bases and their derivatives. The superiority of the purine ribotides is not unusual (Fig. 2); several purine- and pyrimidine-requiring mutants of Ophiostoma spp. utilized the ribosides and ribotides better than the free bases (Fries, 1946); analogously, a strain of Haemophilus parainfluenzae used the pyrimidine ribosides and ribotides more effectively than free uracil (Herbst \& Snell, 1949). S. flavocyaneus uses the three isomers of adenylic acid (adenosine-2'-phosphate, adenosine-3'-phosphate and adenosine- $5^{\prime}$-phosphate) and inosine- $5^{\prime}$-phosphate equally well. Lactobacillus case $i$ used the $3^{\prime}$ isomer of adenylic acid better than the $\mathbf{2}^{\prime}$ or $5^{\prime}$ isomer (Balis \& Elion, 1952). Whether the coccus converts the $2^{\prime}, 3^{\prime}$, and $5^{\prime}$ ribotides into a single member of this group or into another as yet unknown ribotide precursor of polynucleotides is unknown.

The imidazoles used here are of interest as possible precursors of nucleic acid purines (Greenberg, 1953). In the coccus, utilization of 4-amino-5imidazolecarboxamidine (the adenine analogue) for growth is about twice as great as that of 4-amino-5-imidazolecarboxamide (the hypoxanthine analogue). 
The amidine may be closer to the main pathway of purine synthesis than the carboxamide: it is more active and it provides a simpler pathway to adenine and one which bypasses hypoxanthine.

Inhibition of growth by purines and their derivatives. Growth inhibition by purines and their derivatives, natural and unnatural, has been reviewed by Roblin (1954) and by McNutt (1952). Guanine and other purines found in nucleic acids are inhibitors for several organisms (Pennington, 1942; Fairley \& Loring, 1949; Fries, 1949). In some instances purine analogues such as 8-azaguanine, 2:6-diaminopurine or 6-mercaptopurine have offered promise in the inhibition of neoplasms (Gellhorn, Hirschberg \& Kells, 1954; Law, 1950; Conference on 6-mercaptopurine, N.Y. Acad. Sci., 1954, various authors). Several hypotheses have been advanced to explain the interference with metabolism by purines and their derivatives. Fairley \& Loring (1949), finding that guanine inhibited hypoxanthine but not adenine in a Neurospora mutant which required either adenine or hypoxanthine, suggested that guanine interfered with the amination of hypoxanthine. This does not explain the greater inhibition by guanine of adenine as compared with hypoxanthine in Staphylococcus flavocyaneus. Pennington (1942) thought that the inhibition by guanine of Spirillum serpens, which required adenine or hypoxanthine, was attributable to the need for a complex of two purine bases. Either two hypoxanthines or an adenine and a hypoxanthine molecule could make up the complex; guanine could be part of the complex only in the presence of either adenine or hypoxanthine. Staphylococcus flavocyaneus grows maximally with either adenine or hypoxanthine alone. There is no evidence that the addition of another base, i.e. adenine, hypoxanthine, or even guanine, increased growth appreciably; there was a small stimulation of growth in the presence of noninhibitory amounts of guanine (Fig. 3).

Kalckar (1953) suggested two hypotheses to explain the growth inhibitions caused by purines and their derivatives: (1) unnatural purines divert pentose from synthetic pathways and thus interfere with nucleic acid synthesis; (2) unnatural purines form unnatural nucleic acids which then cannot function properly in their biological role and thus interfere with growth. Results with Staphylococcus flavocyaneus may support the first hypothesis. Here inhibition caused by 2:6-diaminopurine or isoguanine is completely annulled by adenosine and adenylic acid while the guanine inhibition is reversed only partially at the concentration of purine used (Table 4). Ribose-containing purine derivatives are exceptionally effective in overcoming the inhibition by guanine (Fig. 3). In recent experiments, D-ribose overcame inhibition by guanine in the presence of growth-promoting purine; further investigations are in progress. At low concentrations $\left(1.8\right.$ or $1.9 \times 10^{-2} \mu$ mole $/ 5 \mathrm{ml}$.) of hypoxanthine, adenine and adenylic acid, growth is completely inhibited at the concentrations of guanine tested, while at a molar equivalent of adenosine growth is only partially inhibited. At 10 times the preceding concentrations adenine and hypoxanthine are still unable to annul the inhibition while adenylic acid partially annuls and adenosine almost completely annuls the inhibition of growth by guanine. The ribose-containing compounds may annul the blocking 
of ribose utilization. The low solubility of guanine precludes trials of higher concentrations. The effectiveness of ribosides in overcoming inhibitions by purines and their analogues is in keeping with their effectiveness in suppressing the mutagenic activity of various purine analogues toward Escherichia coli (Novick \& Szilard, 1952).

Kalckar's second hypothesis is supported indirectly by the isolation of ribonucleic acid which contains 8-azaguanylic acid from Escherichia coli, Staphylococcus aureus, and both normal and tumour tissue of mice treated with 8-azaguanine (Lasnitzki, Matthews \& Smith, 1954) and the demonstration by Matthews (1953) that 8-azaguanine is incorporated into nucleotides of tobacco mosaic virus. In addition, Jeener (1954) noted that the incorporation of thiouracil into ribonucleic acid of tobacco mosaic virus resulted in fewer infective virus particles.

Inhibition by various purine analogues, especially by 8 -azaguanine and 2:6-diaminopurine, is annulled by the purine bases. In several systems (psittacosis virus, Morgan, 1952; vaccinia virus, Thompson, Price, Minton, Elion \& Hitchings, 1950; Ophiostoma sp., Fries \& Panders, 1950; 'killer' action of Paramoecium aurelia, Williamson, Jacobson \& Stock, 1952; cell division of plant tissues, Miller, 1953) inhibition by 2:6-diaminopurine is annulled by adenine. Inhibition of Lactobacillus casei and of Tetrahymena geleii by 8-azaguanine is annulled by guanine(Hitchings, Elion, Falco, Russel, Sherwood \& Vanderwerff, 1950; Kidder \& Dewey, 1949). In these systems the natural purine base may prevent the incorporation of the unnatural purine into nucleic acid.

As noted in the introduction, free guanine inhibits several purine-requiring micro-organisms besides Staphylococcus flavocyaneus. It is unlikely that guanine, a normal component of nucleic acid, forms abnormal nucleic acids when supplied exogenously. It would seem more likely that excess of exogenous guanine competes with required exogenous purines for pentose in nucleic acid synthesis, thus leading to a block in normal nucleic acid metabolism.

This paper reports work begun during the tenure of an Atomic Energy Commission predoctoral fellowship in the biological sciences.

\section{REFERENCES}

Baker, H., Sobotka, H. \& Hutner, S. H. (1953). Growth requirements of some thermophilic and mesophilic bacilli. J. gen. Microbiol. 9, 485.

Balis, M. \& Elion, G. B. (1952). Utilization of some purine ribose derivatives by Lactobacillus casei. Fed. Proc. 11, 183.

Buchanan, J. G., Dekker, C. A. \& Long, A. G. (1950). The detection of glycosides and non-reducing carbohydrate derivatives in paper partition chromatography. J. chem. Soc. 19, 3162.

Carter, C. E. (1950). Paper chromatography of purine and pyrimidine derivatives of yeast ribonucleic acid. J. Amer. chem. Soc. 72, 1466.

Conference on 6-mercaptopurine (various authors), N.Y. Acad. Sci. 1954. In the press.

Fairley, J. L. \& Loring, H. L. (1949). Growth-promoting activities of guanine, guanosine, guanylic acid, and xanthine for a purine-deficient strain of Neurospora. J. biol. Chem. 177, 451. 
Fries, N. (1946). Mutant strains of Ophiostoma multi-annulatum requiring components of different nucleotides. Ark. Bot. 33A, 1.

Fries, N. (1949). Effects of different purine compounds on the growth of guaninedeficient Ophiostoma. Physiol. Plant. 1, 78.

Fries, N. \& Panders, A. (1950). The growth-inhibiting effect of 5-amino-7-hydroxytriazolopyrimidine in fungi and its reversal by purines. Ark. Bot. 2 (N.S.) 437.

Gellhorn, A., Hirschberg, E. \& Kells, A. (1954). The effect of purines, nucleosides, and nucleotides on the carcinostatic action of 8-azaguanine. J. nat. Cancer Inst. 14, 935.

GreenberG, G. R. (1953). Mechanisms involved in the biosynthesis of purines. Fed. Proc. 12, 651.

Herist, E. J. \& SNELl, E. E. (1949). The nutritional requirements of Hemophilus parainfluenzae 7901. J. Bact. 58, 379.

Hitchings, G. H., Elion, G. B., Falco, E. A., Russel, P. B., Sherwoon, M. B. \& VANDERWERFF, H. (1950). Antagonists of nucleic acid derivatives. I. The Lactobacillus casei model. J. biol. Chem. 183, 1.

JEENER, R. (1954). Influence of thiouracil incorporation in the ribonucleic acid moiety of tobacco mosaic virus on its multiplication. Biochim. Biophys. Acta, 13, 148.

KaLCKAR, H. M. (1953). Role of phosphoglycosyl compounds in the biosynthesis of nucleosides and nucleotides. Biochim. Biophys. Acta, 12, 250.

KIDDER, G. W. \& DewEY, V. C. (1949). The biological activity of substituted purines. J. biol. Chem. 179, 181.

KNAYSI, G. (1942). The demonstration of a nucleus in the cell of a staphylococcus. J. Bact. 43, 365.

LASNitzki, I., Matthews, R. E. F. \& Smith, J. D. (1954). Incorporation of 8-azaguanine into nucleic acids. Nature, Lond. 173, 346.

LAw, L. W. (1950). Studies on the effects of a guanine analog on acute lymphoid leukemias of mice. Cancer Res. 10, 186.

McNutr, W. S. (1952). Nucleosides and nucleotides as growth substances for microorganisms. Progress in the Chemistry of Organic Natural Products, 9, 401-442. Edited L. Zechmeister. Vienna: Springer.

Matthews, R. E. F. (1953). Incorporation of 8-azaguanine into nucleic acid of tobacco-mosaic virus. Nature, Lond. 171, 1065.

Muller, C. (1953). Reversible inhibition of cell division and enlargement in plant tissues by 2, 6-diaminopurine. Proc. Soc. exp. Biol., N.Y. 83, 561.

Morgan, H. R. (1952). Factors related to the growth of psittacosis virus (strain 6 BC). II. Purines, pyrimidines, and other components related to nucleic acid. J. exp. Med. 95, $27 \%$.

Northam, B. E. \& Norris, F. W. (1951). Growth requirements of Schizosaccharomyces octosporus, a yeast exacting towards adenine. J. gen. Microbiol. 5, 502.

Novick, A. \& Szilard, L. (1952). Anti-mutagens. Nature, Lond. 170, 926.

Pennington, D. E. (1942). Purines as growth requirements of Spirillum serpens. Proc. nat. Acad. Sci., Wash. 28, 272.

Pomper, S. (1952). Purine-requiring and pyrimidine-requiring mutants of Saccharomyces cerevisiae. J. Bact. 63, 707.

Pontecorvo, G. (1950). New fields in the biochemical genetics of microorganisms. Symp. Biochem. Soc. 4, 40.

Roblin, R. O., Jr. (1954). Metabolite antagonists. Ann. Rev. Biochem. 23, 501.

Trompson, R. L., Price, M. L., Minton, Jun., S. A., Elion, G. B. \& Hitchings, G. H. (1950). Effects of purine derivatives and analogues on multiplication of the vaccinia virus. J. Immunol. 65, 529.

Williamson, M., Jacobson, W. \& Srock, C. C. (1952). Testing of chemicals for inhibition of the killer action of Paramecium aurelia. J. biol. Chem. 197, 763. 